\title{
Household Portfolios in the United States
}

\author{
Carol Bertaut and Martha Starr-McCluer \\ Federal Reserve Board of Governors
}

April 2000

This paper investigates the composition of households' assets and liabilities in the United States. Using aggregate and survey data, we document major trends in household portfolios in the past 15 years. We show that, despite the broad array of financial products available, the portfolio of the typical household remains fairly simple and safe, consisting of a checking account, savings account, and tax-deferred retirement account; in 1998, less than half of all households owned some form of stock. We use pooled data from the Survey of Consumer Finances to investigate determinants of portfolio choice, finding significant effects of age, wealth, income risk, and entry/information costs.

This is a revised version of a paper presented at the European University Institute's Conference on Household Portfolios, held in Florence, Italy, December 17-18, 1999. We are grateful to Dan Bergstresser, Darrel Cohen, Diana Hancock, Tullio Jappelli, Arthur Kennickell, Dean Maki, Maria Perozek, Nick Souleles, and Sandy Struckmeyer for valuable comments on earlier versions of this paper. The views expressed in this paper are those of the authors and not necessarily those of the Federal Reserve Board or its staff. 


\section{Household Portfolios in the United States}

\section{Introduction}

In deciding how to structure their assets and liabilities, American households face a broad array of options. Savings can be allocated to a wide range of assets, from simple bank accounts to sophisticated assets like real estate investment trusts. Credit is available from many types of institutions -- banks, credit unions, finance companies, credit cards -- with all kinds of borrowing terms: loans versus lines of credit, fixed or variable interest rate, and secured or unsecured loans. Deregulation, easy entry, and developments in information technology have been important in the proliferation of financial products.

Given the relatively liberal U.S. financial environment, it is perhaps surprising that the portfolios of American households tend to be very simple and safe. In 1998, the typical household had three types of financial assets, most frequently a checking, savings, and taxdeferred retirement account; less than one-half of all households had any type of investment in stock. There is also quite a lot of borrowing in costly forms like credit cards, and from costly sources like finance companies. Even in the top quintile of the income distribution, portfolios tend to be fairly undiversified, with some borrowing in the form of high cost debt.

Understanding these puzzles may shed light on why households select the assets and liabilities that they do.

While there has been a considerable amount of research on household saving behavior, the portfolio decisions of households are less well understood. Some studies have examined the equity premium, borrowing constraints, and information and transactions costs (see King and Leape, 1998; Haliassos and Bertaut, 1995; Blume and Zeldes, 1994). But there has been little systematic investigation of household portfolio behavior to date. There are several reasons why this gap needs to be filled. First, because returns vary across assets and costs vary across debts, portfolio decisions have important implications for the pace of wealth accumulation -- and thus for such issues as the adequacy of precautionary saving and degree of retirement preparedness. Second, differences in portfolios across households may shape the response of aggregate consumption to changes in macro variables or fiscal policies. For example, ownership of stock wealth is concentrated among wealthy households, who may have a relatively low propensity to consume stock wealth gains. Third, the behavior of individual investors impinges directly on 
questions about the efficiency of financial markets (Shiller 1997). And finally, understanding households' portfolio decisions may also provide richer insights into theories of consumption and saving behavior.

This paper provides an in-depth review and analysis of household portfolios in the United States. The next section of the paper describes trends in the structure of household portfolios in the past 15 years, using both aggregate and survey data. We document the growth of tax-deferred retirement plans, the increased role of equity, and the shift toward home equity-based borrowing. We also update previous comparisons between the SCF and aggregate data from the Flow of Funds. The third section of the paper presents evidence on the structure of household portfolios from the SCF and discusses previous research in the field. The fourth part of the paper estimates econometric models of the determinants of portfolio choice, including age, wealth, income risk, entry and information costs, and liquidity constraints. We focus on the role of risky assets in household portfolios, but also consider joint decisions to hold assets and liabilities; joint decisions are investigated using (for the first time, to our knowledge) a multivariate probit approach. The final section draws implications of our findings, especially those for understanding how household portfolios respond to changes in fiscal policy, macroeconomic variables, and financial innovations.

\section{Data on household portfolios}

Aggregate data on households' assets and liabilities are available from the Federal Reserve Board's Flow of Funds accounts (FFA). The FFA are compiled from institutional sources and provide a comprehensive view of households' holdings; they include both assets and liabilities held directly by households, as well as by pension funds held on households' behalf. Table 1 shows some broad trends in household portfolios from 1983 to 1998. ' (Note that, while published figures from the FFA on the 'household sector' include the assets and liabilities of nonprofit organizations, the figures presented here remove the holdings of nonprofits). ${ }^{2}$

\footnotetext{
'All dollar figures in the tables and text are adjusted to 1998 terms using the "current methods" version of the consumer price index for all urban consumers (Stewart and Reed, 1999). ${ }^{2}$ At present, FFA estimates of nonprofit holdings are available through 1996 only, due to lags in the availability of the source data. For 1998, we estimated holdings of nonprofits in 1998 by taking total (i.e. household plus nonprofit) holdings in 1998 and assuming that nonprofits held
} 
Throughout this period, the single most important item in aggregate household assets was residential property; nonetheless, its share of total assets slid from $28 \%$ in 1983 to $22 \%$ in 1998 . For households overall, the relative importance of financial assets increased substantially over this period, rising from about $45 \%$ to $61 \%$ of total assets. The composition of financial assets also shifted appreciably, with the relative importance of time and savings deposits declining while the importance of pension funds, corporate equity, and mutual funds rose.

Several factors underlie these trends. The first and most important consideration is the sustained growth in stock prices over the period. As shown in Figure 1, the S\&P 500 stock price index rose from 165 in 1983 to 600 in 1995 and 1,100 in 1998; ${ }^{3}$ with inflation subdued for most of this period, this represents an average real increase of over $10 \%$ per year. Second, whereas mutual funds represented a narrowly-held specialty product before the 1980s, after that time the industry grew dramatically, with the number of funds rising from 564 in 1980 to 6,778 in 1998 (Investment Company Institute, 1998). The large array of institutions offering mutual funds, the proliferation of types of funds available, and the rise of no-load funds have made it easier and less costly for investors to acquire a diversified portfolio of stock.

A third major trend during this period was the introduction of tax-deferred retirement accounts. Most households could make tax-deductible contributions to Individual Retirement Accounts (IRAs) between 1983 and 1986; although broad deductibility was curtailed in 1986, IRA balances have continued to grow due to capital gains, rollovers from 401(k)-type accounts, and contributions from self-employed persons. ${ }^{4}$ Additionally, following a Treasury ruling in the early 1980s, pension coverage started to shift away from traditional defined-benefit (DB) plans, in which employees receive a fixed payment based on salary and years of service, and toward 401(k)-type defined-contribution (DC) plans, in which employees and/or employers make contributions to retirement accounts. For employees, 401(k)-type plans have the advantages that both contributions and returns are tax-deferred, vested balances are portable, employees often have investment options, and they may be able to borrow or make withdrawals from the account.

the same share of the total as in 1996. This assumption seems reasonable, given the small movements in the shares over the period for which separate estimates are available. ${ }^{3}$ Year-end figures.

${ }^{4}$ More recently, the 1997 tax bill introduced Roth IRAs, for which contributions are taxed but withdrawals are not. 
Fourth, the combination of rising stock prices and the growth of stock investment through mutual funds and retirement accounts has been associated with a significant increase in the equity share of households' financial assets. As shown at the bottom of table 2, the share of householdsector financial assets invested in corporate equities -- either directly or through a mutual fund, retirement account, other managed asset, or DC pension fund -- rose from 15\% in 1983 to $35 \%$ in 1998. In terms of total household assets, this rise put households' total stockholdings about on par with residential property at the end of 1998.

The final and related point concerns the role of equity in residential property. Equity in residential property dwindled in importance in the 1990s, with its share of total household wealth falling from $22 \%$ in the 1980 s to about $15 \%$ in 1998 . The decline partly reflects the relatively slow growth of housing prices: between 1983 and 1998, median home prices less than doubled, compared to the sixfold increase in stock prices (Figure 1). But factors on the liability side of the household balance sheet also contributed to this trend. Notably, whereas households used to be able to deduct all types of interest payments from their taxable income, the Tax Reform Act of 1986 limited deductibility to interest payments on debt backed by home equity. ${ }^{5}$ This change increased the relative attractiveness of borrowing against the primary residence, contributing to a rise in the share of mortgage debt in total household borrowing and a rise in the ratio of mortgage debt to the value of residential property. ${ }^{6}$

While the aggregate data describe the portfolios of the household sector overall, they do not directly portray developments in the typical household portfolio. Ownership of some assets, notably stock and bonds, is quite concentrated at the top of the wealth distribution, so, for example, it is not necessarily clear whether the shift toward risky financial assets is broad-based. To examine trends at the household level, we look at data from the Federal Reserve Board's Survey of Consumer Finances (SCF). Conducted triennially since 1983, the survey collects detailed information on households' assets, liabilities, incomes, and other characteristics. ${ }^{7}$ In

\footnotetext{
${ }^{5}$ The limits were phased in over a five-year period. See Poterba (1999) and Maki (1996) for further analysis of this subject.

${ }^{6}$ See Maki (1996). Increased leverage may also reflect incentives to channel funds into retirement accounts, rather than pay down tax-preferred debt (Engen and Gale, 1997). ${ }^{7}$ See Kennickell, Starr-McCluer, and Surette (2000) for an overview of the SCF. Because respondents often have incomplete information on their holdings or may be unwilling or unable
} 
recent years, the SCF sample has consisted of about 3,000 households drawn from a standard representative sample, supplemented by some 1,500 households drawn from a special highwealth oversample based on tax records. In descriptive analysis, sample weights can be used to make the data representative of the population as a whole. This "dual frame" sample design provides adequate representation of both broadly-held items, like homes and vehicles, and other items, like stocks and bonds, held disproportionately by the wealthy. The SCF's special sample and detailed information make it uniquely well suited for investigating the portfolios of U.S. households. ${ }^{8}$

Table 2 presents some basic descriptive statistics from the SCF. Because of concerns about nonreporting in survey data on wealth, it is of interest to know how the SCF compares to the Flow of Funds. As the table shows, estimates of average household wealth from the SCF have been about $10 \%$ to $20 \%$ below estimates for the same period from the FFA. ${ }^{9}$ While it may be tempting to attribute the divergence to underreporting by households, there are a number of conceptual differences between the two data sources that at least contribute to the divergence. Notably, the FFA include some items not collected in the SCF (i.e. currency holdings, DB pension reserves, and durable goods other than vehicles), and these may well outweigh the items included in the SCF but not the FFA (nonresidential property, and miscellaneous valuable assets such as artwork and antiques). A careful study by Antoniewicz (1996) found that, after adjusting for conceptual differences between the FFA and SCF, the two

to report details, the SCF data are carefully cleaned and edited, and missing values are systematically imputed.

${ }^{8}$ Note that the survey's scope for examining dynamic issues is limited by its cross-section design. This design is necessitated by the survey's main objective of providing representative information on household finances, along with the practicalities of the dual sample frame; for example, it is not possible to conduct regular re-interviews with the high-wealth cases. For analysis of SCF panel data collected in the 1980s, see Kennickell and Starr-McCluer (1997). ${ }^{9}$ Although the surveys since 1992 have been about $20 \%$ below estimates of household wealth from the Flow of Funds, there is no clear reason why the 1990s surveys would capture a smaller share of FFA wealth than the 1980s surveys. The survey's sample design, questionnaire, and imputation methods were revised considerably in 1989, and in 1992 the area-probability sample frame was updated to reflect data from the 1990 Census; if anything, these improvements would be expected to raise the share of aggregate wealth captured by the survey. One factor may relate to the composition of the 1983 oversample, which was based on income, rather than estimated wealth; also, respondents had to volunteer to participate in the survey. 
data sources tend to square fairly well, although the SCF estimates of financial assets remained somewhat below comparable measures from the FFA. ${ }^{10}$

Tables 2 and 3 show trends in ownership and holdings of assets and liabilities using the SCF data. Many of the trends seen in the aggregate data are also apparent in the micro data. The share of liquid accounts -- including checking, savings, money market, and call accounts -- in total assets has edged down since 1989, although the share of households owning such accounts has remained above 85 percent. The period also saw declining ownership of several types of traditional investments -- including certificates of deposit, U.S. savings bonds, other bonds, and cash-value life insurance - reflecting the relatively unattractive returns to these products and proliferation of higher-return alternatives like mutual funds. Mutual fund ownership rose from some $5 \%$ of households in 1983 to over $16 \%$ in 1998, and while direct ownership of stock actually drifted down between 1983 and 1995, it moved back up in 1998. The share of households having a tax-deferred retirement account --either IRA or 401(k)-type-- rose from about $31 \%$ in 1983 to $48 \%$ in 1998 .

As a result of the combination of broader ownership of equity and rising prices, the share of households owning publicly-traded stock -- either directly or indirectly through a mutual fund, retirement account, or other managed asset -- rose substantially, from $31.6 \%$ in 1989 to almost $49 \%$ in 1998." This expansion has been broad-based across income, age, and education groups, so that the composition of stockholders has changed somewhat: stockowners in 1998 were

\footnotetext{
${ }^{10}$ Two other issues are worth mentioning. First, in the FFA, households' holdings are computed as a residual, that is, by taking total holdings of a given asset or liability and subtracting out holdings attributable to other sectors. While there is no a priori reason to believe that this imparts a systematic bias to the household numbers, uncertainties in allocating funds across sectors may leave some scope for measurement error. Second, for practical reasons, the SCF does not sample households at the very top of the wealth distribution, such as those whose net worth would place them in the Forbes 400 range (for example, in 1998 the cut-off to make it into the Forbes 400 was net worth of $\$ 500$ million). This omission causes only modest understatement of total household wealth. For example, the total net worth of the Forbes 400 was $\$ 745$ billion in 1998 , compared to an estimate of $\$ 28,850$ billion from the SCF - suggesting understatement in the SCF on the order of $2-1 / 2 \%$.

${ }^{11}$ This share cannot be directly computed for 1983, since that survey lacks information on the composition of investments in mutual funds, retirement accounts, and trusts and other managed assets. Using information on investment compositions in 1989 to impute compositions in 1983, Poterba and Samwick (1995) estimate that 33.2 percent of households held stock in some form in 1983.
} 
somewhat younger than stockowners in 1989, and their median income and wealth were lower (Appendix Table A). ${ }^{12}$ Nonetheless, stockownership has traditionally been concentrated in the upper tail of the wealth distribution, and the recent expansion of ownership has not altered this picture: for example, the share of total household equity held by the top $5 \%$ of the wealth distribution essentially held steady between 1989 and 1998.

The broadening of stockownership in the U.S. is an important change, yet its causes and implications are not well understood. Certainly declining information and transactions costs have had an influential role. Technological innovation substantially lowered institutions' costs of processing financial information; in the competitive, lightly regulated capital markets characteristic of the U.S., this encouraged entry by mutual fund companies and discount brokerages, and drove down fees and minimum investments. ${ }^{13}$ Employer-sponsored retirement accounts introduced an easy way to acquire equity investments: employers pre-select the investment options; choices must be described in a clear, jargon-free way; there is no minimum investment; etc. More recently, the Internet has begun to facilitate significantly the collection of financial information and conduct of financial transactions, although at present only a small part of the population makes use of this potential. ${ }^{14}$ But in addition to the role of declining information costs, the economic climate was unusually good in the 1990s, with declining unemployment, solid real income growth, and booming stock prices; no doubt these factors also made households feel more comfortable about investing in stock.

In addition to the broadening of stockownership, the survey data also document the declining relative importance of home equity in household wealth. ${ }^{15}$ According to the survey

\footnotetext{
${ }^{12}$ Also note that, in $1989,15 \%$ of equity owners had shares in one company only; by 1998 this share had falled below $5 \%$.

${ }^{13}$ According to the Investment Company Institute, the average cost of investing in equity mutual funds, including all major fees and expenses, fell by one-third between 1980 and 1997 (Rea and Reid 1998).

${ }^{14}$ For example, only $8 \%$ of respondents to the 1998 SCF reported using the Internet or online services to make decisions about savings and investments. However, this share rose with household income, so that among households with incomes of $\$ 100,000$ or more, about $22 \%$ said they used the Internet to this end.

${ }^{15}$ Note that the FFA series on residential property includes all 1-4 family homes, not just the primary residence; other types of property are attributed to other sectors. The SCF distinguishes between the primary residence and other property owned by households (residential and
} 
data, for households overall, equity in the primary residence declined from $28 \%$ of net worth in 1983 to $21 \%$ in 1998 . For the typical homeowner, home equity represents a larger share of their total wealth than this overall share implies: for example, the median share among homeowners was $43 \%$ in 1998. But the median share is also considerably lower now than it was in the 1980s, due to growth in retirement accounts and other stock-based assets in homeowners' portfolios, along with the trend toward greater leverage associated with the home.

Finally, the share of households having credit card debt rose appreciably over the 1983-98 period. This is a period when bank-type credit cards became widely available in the U.S., especially in the first half of the 1990s when credit card solicitations filled households' mailboxes. ${ }^{16}$ The widespread use of credit card debt in the U.S. is somewhat puzzling, considering the relatively high interest rates on credit card debt; even with the competition and low introductory rates, the average interest rate on bank-type credit cards remained above $15 \%$ in 1998 , versus about $8 \%$ for a home-equity loan. ${ }^{17}$

\section{Evidence on the structure of household portfolios}

In simple portfolio models, investors allocate funds across assets with different risks and returns; optimization results in diversified portfolios, with the relative importance of different assets reflecting investors' risk and time preferences. Of course, such simple models abstract from several important aspects of the household portfolio problem. In particular, (1) investors also face background risk associated with labor earnings and business income; (2) a key investment option, housing, yields consumption flows as well as investment returns, and its price may covary with income; (3) there may be information and transactions costs that vary across investments and across individuals; and (4) households' portfolio decisions may partly reflect a risk of facing liquidity constraints.

commercial). According to the $1995 \mathrm{SCF}$, primary residences represented about 86 percent of the total value of residential property owned by households.

${ }^{16}$ The share of households having at least one bank-type card (Mastercard, Visa, Optima, and Discover) rose from $43 \%$ in 1983 to $67 \%$ in 1998 . Among households having cards, the share with balances outstanding after the last month's payments moved up from 52\% to $55 \%$.

${ }^{17}$ The average credit card interest rate is from the Federal Reserve Board's G19 statistical release, and the home equity loan rate is from HSH Associates, Financial Publishers. For additional discussion, see Ausubel (1991) and Calem and Mester (1995). 
Table 4 provides some basic stylized facts on the structure of U.S. households' financial assets, using data from the 1998 SCF. The vast majority of households have only a few types of financial assets: of the thirteen main categories of financial assets in the SCF, the average number per household was $3 .^{18}$ Some $7 \%$ of households had no financial assets whatsoever; another $15 \%$ had only one asset, most commonly a checking account. Another $53 \%$ of households had 2 to 4 types of assets, typically a checking account along with a savings account, retirement account, and/or cash-value life insurance. The remaining $25 \%$ of households had 5 or more types of assets; items like directly-held stock and mutual funds become common only among households having 7 or more types of assets.

The incompleteness of the typical portfolio may partly have to do with entry, information and transactions costs. Some items, like brokerage accounts and mutual funds, require minimum investments. For example, of the top-ranked mutual funds in a recent Consumer Reports review, the average minimum investment was $\$ 2,000$ for non-retirement accounts; such funds would be inaccessible to the $32 \%$ of households with non-retirement financial assets below this level. ${ }^{19}$ Also, whereas opening a checking account is fairly straightforward, it takes time to learn how to invest in other assets and to manage them over time (quarterly statements, tax returns, etc). ${ }^{20}$ Thus, for example, King and Leape (1987) found that the probability of owning an asset rises with age, even after controlling for the lifecycle profile in wealth; they interpret this finding as consistent with a model in which information about investment opportunities arrives stochastically over time. Using data from the Panel Study of Income Dynamics, VissingJorgenson (1999) documents appreciable costs of entry and participation in the U.S. stock market, with the latter on the order of \$100-200 per year. ${ }^{21}$ Haliassos and Bertaut (1995) and Bertaut (1998) also identify a role of information costs in deterring investment in stock.

\footnotetext{
${ }^{18}$ The median was also 3.

${ }^{19}$ See "Mutual Funds: Pieces of the Action," Consumer Reports, March 2000, pp. 27-35. Consumer Reports limits its review to no-load mutual funds that have relatively low expense ratios and no $12 \mathrm{~b}-1$ fees. Minimum investments are often much lower for retirement accounts. ${ }^{20}$ For example, in their study of tax compliance, Blumenthal and Slemrod (1992) found that filing the return for capital gains on investments increased total filing time by six hours.

${ }^{21}$ Apparently in 1982-84 dollars.
} 
As Table 5 shows, there is a clear correlation between wealth and the structure of household portfolios. ${ }^{22}$ Ownership of almost all types of assets and liabilities rises with wealth; the only exceptions are credit card balances and other consumer debt (left panel). As wealth rises, the shares of total assets held in homes and "other" nonfinancial assets (mostly vehicles) decline, while the shares in stocks, bonds, mutual funds, trusts and other managed assets, businesses, and other real estate rise; the share of all forms of publicly-traded stock in total assets also rises (center panel). The variation in portfolio structure across the wealth distribution, combined with the concentration in wealth ownership, implies large differences in concentration across assets and liabilities. For example, households in the top 5\% of the wealth distribution own $57 \%$ of total net worth, but their shares are considerably higher for stocks, bonds, trusts and other managed assets, business equity, and investment real estate (right panel). The only items where the distribution of holdings is anything close to proportionate are credit card balances and other consumer debt.

Variations in asset composition imply differences in the riskiness of households' portfolios. To gain more insight into this question, we divide financial assets into three broad categories reflecting their degree of risk: (1) "safe" financial assets, including liquid accounts (checking, saving, money market, and call), certificates of deposit, and U.S. savings bonds; (2) "fairly safe" financial assets, including other government bonds, tax-free bonds, cash-value life insurance, and amounts in mutual funds, retirement accounts, and trusts and other managed assets that are not invested in stock; and (3) "fairly risky" assets, including stocks held directly or through mutual funds, retirement accounts, and trusts and other managed assets, and corporate, foreign and mortgage-backed bonds. While this categorization may have some arbitrary aspects, the main findings reported here are robust to minor changes in classification - as long as liquid accounts are classified as "safe" and stock-based assets are classified as "fairly risky."

In the four most recent SCFs, about one-quarter of all households had safe assets only (Table 6). About one-quarter of households had "safe and fairly safe" assets in 1989, with this category steadily losing ground over the 1990s. The categories into which households moved were "safe, fairly safe, and fairly risky" and "safe and fairly risky"; together these categories had almost half of all households in 1998, up from about one-third of households in 1989. Not

\footnotetext{
${ }^{22}$ For early evidence on wealth and portfolio composition, see Uhler and Cragg (1971).
} 
surprisingly, these shifts, combined with the run-up in stock prices, boosted the share of households' financial assets held in risky forms, to $55.3 \%$ in 1998 . Nonetheless, this figure overstates the relative importance of risky assets in the typical household's financial portfolio: for example, among all households, the median share of financial assets held in risky items was just $4 \%$ in 1998.

With financial assets comprising only one part of the portfolio picture, it may also be important to consider other risky assets held by households. Thus, Table 6 also shows a more general measure of risk, including business equity and investment real estate, as well as risky financial assets. Here too the share of households having some type of risky asset rose between 1989 and 1998, so that by 1998 the share of total household assets held in risky forms reached almost $50 \%$. But again, for the median household, risky assets represented only a small part of their total assets (5\% in 1998).

A classic issue in portfolio studies concerns the tendency for risk to vary with age. As shown in Table 7, the share of households having risky financial assets is generally highest in the prime-age years and drops off in the older age ranges. The share of risky assets in total financial assets was highest in the 45-54 group in the 1989 and 1992 surveys, and in the 55-64 age group in 1995 and 1998. The measures of broader portfolio risk also show risk-taking to be highest in the 35-64 age ranges. Of course, the patterns in the data may reflect both age and cohort effects, and it is not straightforward to separate these two. ${ }^{23}$ Nonetheless, the survey data show that, for virtually all age groups and for both risk measures, the percentages of households owning risky assets have risen substantially over time; only in the over-75 age group has ownership of risky assets held steady.

Several factors may underlie this age/risk profile. First, younger people face more background risk in their human capital, which could temper their demand for stocks. As they enter prime-age years and uncertainty about lifetime income declines, they may take on more financial risk (see Gollier, 1999). Second, young and prime-aged people have greater labor supply flexibility than older people, so if the returns to their investments turned out to be low, they could work more or retire later (Bodie, Merton, and Samuelson, 1992). In contrast, older

\footnotetext{
${ }^{23}$ See Ameriks and Zeldes (2000) for a full discussion of this issue. Poterba and Samwick (1997) use a cohort approach to analyze data from the 1983, 1989, and 1992 SCFs.
} 
people would have to reduce consumption in line with their income, and so may choose to limit their risk. A third factor concerns the fact that initial investment in housing is large and indivisible. For example, Flavin and Yamashita (1998) show that, because younger households have highly leveraged portfolios typically dominated by housing wealth, they should use their cash flow to pay down their mortgages or invest in safe assets, rather than buy stock. In contast, older households have built up their assets and reduced their ratios of housing to net worth, and so can allocate higher shares of their financial assets to investments in stock. Fourth, other sources of uncertainty in old age may also temper willingness to take risk, such as uncertainty about the length of life and the risk of large health or nursing care expenses. Finally, younger people may have not yet learned about characteristics of risky investments, as mentioned above.

\section{Econometric analysis}

To gain further insight into the structure of household portfolios, we estimate models of portfolio structure as a function of age, wealth, and a number of household characteristics that may figure into portfolio decisions. With cross-section data, we have limited means of accounting for unobserved heterogeneity or dynamic aspects of asset ownership. However, we do have a large number of observations from the full distribution of wealth, carefully cleaned and edited data, and a rich array of background data on household characteristics. Thus, while our results are primarily suggestive of the effects of age and wealth on household portfolios, they nonetheless provide considerable insight into determinants of portfolio structure.

The first part of this section focuses on the position of risky assets in household portfolios. Using limited-dependent variable specifications and pooled data from the 1989, 1992, 1995, and 1998 SCFs, we show that determinants of the decision to hold risky assets may differ from the determinants of the risky share; this is suggestive of differences in entry or information costs across households. We also show that, controlling for wealth, income, and other factors, the probability of having risky assets is significantly higher for prime-aged households, than for households in the under-35 or over-65 age ranges; in contrast, age effects on the risky share are not always significant. The second part of the section takes a broader approach to household portfolios, examining joint decisions to hold assets and liabilities. Here we take advantage of recent advances in simulation methods and estimate a multivariate probit model of such 
decisions. Broadly, the results suggest an important role of life-cycle considerations in shaping household portfolios, as well as income risk, liquidity constraints, and differences across assets and households in information costs.

\section{Holdings of risky assets}

Econometric analysis of household portfolios must take into account the fact that many households have no risky assets at all. ${ }^{24}$ With cross-section data, this problem can be approached in two possible ways. First, the household may hold the risky asset only if its optimal portfolio share exceeds some minimal level; then the optimal share is observed only if it above this threshold, and data on nonowners convey only the probability of being below this level. This is a censored regression model, and can be estimated using Tobit. Second, the process underlying the decision to hold risky assets may differ from that determining the optimal share, for example, if participation reflects lack of information on the asset or its characteristics; in this case, the ownership decision should be modeled separately from the process generating the portfolio share. This model can be estimated as a probit for ownership and a truncated regression among households having risky assets, and has the advantage of allowing a test of the assumptions of the Tobit. Third, if the ownership and share decisions are separate, but have unobserved determinants that are correlated, a sample selection approach is warranted. To determine the relevant approach, we estimate and compare all three models, considering both risky financial assets as a share of financial assets, and total risky assets as a share of total assets.

To take full advantage of the SCF data, we pool the data from the 1989, 1992, 1995, and 1998 surveys, using time dummies to indicate the survey year (1995 is omitted). As discussed in Ameriks and Zeldes (2000), this approach assumes that cohort effects are equal to zero. ${ }^{25}$ Excluded from the analysis are 1,029 households that have no financial assets whosoever on the grounds that, without assets, they face no decision about portfolio composition. ${ }^{26}$ This leaves a

\footnotetext{
${ }^{24}$ For discussion, see Miniaci, Pelizzon, and Weber, 1999.

${ }^{25}$ In the period covered by our data, time effects seem likely to be more important than cohort effects, given the strong growth in stockownership from the spread of retirement accounts, the boom in stock prices, and the reversal in the downtrend in direct stockownership.

${ }^{26}$ This avoids equating the decision not to have assets with the decision not to hold risky assets. Including households without assets affects the magnitudes of estimated coefficients, but with little qualitative effect on results.
} 
sample of 14,618 households, of whom 8,310 have risky financial assets and 10,174 have risky assets more broadly defined.

As explanatory variables, we include dummy variables for the age range of the household head: under 35, 35-54 (omitted), 55-64, and 65 and over. ${ }^{27}$ For wealth, we use the log of financial assets in the models for risky financial assets, and the log of total assets in the models for total risky assets. In addition, a number of variables are included to reflect factors likely to shape portfolio decisions. As general household characteristics, we include the log of total household income; the household type (married-couples, households headed by unmarried women, with households headed by unmarried men omitted); ${ }^{28}$ whether the respondent was nonwhite or Hispanic; and the education of the household head (college degree, less than high school diploma, with high school diploma omitted). To capture possible differences in income variability, we include whether the head is self-employed, whether the head or spouse is covered under a defined-benefit pension plan, and the regional unemployment rate. ${ }^{29}$ As a measure of labor supply flexibility, in addition to age, we include a variable indicating whether the household head is retired. To capture variation in risk preference, we include self-reported measures of willingness to take financial risks for commensurate returns (willing to take aboveaverage or substantial risks, not willing to take financial risks, with willing to take average risks omitted).

The results for risky financial assets are reported in Table 8. The Tobit results, shown in the left panel of the table, are consistent with the descriptive statistics: risky shares are lower in both the younger (under 35 ) and the older (55-64, and 65+) age ranges, compared to the 35-54 range, and tend to rise with wealth. Several of the other results are also consistent with expectations: for example, the risky share is lower among self-employed and the retired, and higher among those with DB pension plans, as would be expected from effects of income

\footnotetext{
${ }^{27} \mathrm{We}$ also tried the less flexible but simpler version of age and age-squared, but found it yielded implausible results. In particular, the estimated coefficients suggested a very gentle rise and decline in risky holdings over the life cycle, but with a maximum at age 31-32 - likely an artifact of the specification.

${ }^{28}$ For purposes of this study, married couples include couples living together with shared finances.
} 
uncertainty and labor supply flexibility. However, as mentioned, the Tobit assumes that the decision to hold risky assets directly reflects the optimal share, which may not be warranted if other factors, such as information or entry costs, affect the ownership decision also.

Thus, the next panel of Table 8 shows results from the probit/truncated model, which enable us to test this assumption. Many of the variables have qualitatively similar effects on ownership and share: notably, effects on both are positive and significant for financial assets, having a college degree, and being willing to take high risks, but negative and significant for being self-employed, retired, or unwilling to take financial risks. Coefficients on the time dummies suggest that both ownership and shares have significantly increased over time, ceteris paribus. But some effects differ between ownership and share. Notably, households in the 55-64 and over-65 age ranges are less likely to own stock than households in the 35-54 age range, but among owners, risky shares are not significantly lower in these age groups. Married-couple households have a significantly higher probability of owning risky assets, but a significantly lower risky share; the same is true of female-headed households, although the share effect is significant at a $10 \%$ level only. In fact, the Chi-square test based on the log likelihood rejects the restrictions implied by the Tobit model. This suggests the decisions underlying ownership and portfolio share are indeed not the same.

While useful for testing the restrictions of the Tobit model, the probit/truncated specification does not allow for correlation between unobserved determinants of the ownership and share decisions, as can be done with the Heckman selection model. To estimate this model, we include some variables that may affect the decision to hold risky assets, but not the risky share. Assuming that variation in information and entry costs are important in this regard, we include: the share of household heads employed in financial services in the region, the share of household heads in the region employed in firms with 500 or more workers (correlated with access to equity through tax-deferred retirement accounts), and a measure of how much a household shops around when making decisions about saving and borrowing. ${ }^{30}$

\footnotetext{
${ }^{29}$ Regional variables used in this study are for the nine Census divisions (New England, MidAtlantic, South Atlantic, East South Central, West South Central, East North Central, West North Central, Mountain, and Pacific).

${ }^{30}$ Note that the SCF's 'shopping' questions have been asked somewhat differently in different surveys, with only one question asked in 1989 and 1992, and two asked thereafter; also, the
} 
Results are shown in the right panel of Table 8. The coefficients on the extra information/entry variables have the expected signs and are generally statistically significant; also the correlation in error terms across the two equations is estimated to be positive and significant. Here we see similar mixed results for the coefficients on age: the probability of holding risky assets is significantly lower in the 55-64 and 65+ age ranges, but the risky share is significantly lower for the over-65 group only. Also, the under-35 households show no significant difference in ownership, but their risky share is lower at a $10 \%$ level. Nonetheless, taken jointly, the age variables are significant in the ownership equation, significant in the share equation (albeit at a 10 percent level only), and significant in the selection model overall. ${ }^{31}$ The coefficients on the year dummies also show uptrends in both ownership of risky assets and the risky share over time, and these are jointly significant.

Also as expected, both ownership and share rise with the level of financial assets. Income raises ownership of risky assets, but not the risky share. Conceivably, ownership may be lower among low-income households because their access to equity through retirement plans is more limited; ${ }^{32}$ also, they may anticipate more problems with liquidity constraints, and so keep their assets in safer, more liquid forms. The probability of owning risky assets is also higher for households headed by college graduates, and lower for those without high school degrees. This finding, which is consistent with previous studies, may reflect lower background income risk faced by better-educated households (Hubbard, Skinner, and Zeldes 1995). Additionally, this group may have informational advantages that make it easier or less time consuming for them to invest in stock (Haliassos and Bertaut, 1995); we provide some evidence in favor of this interpretation below.

responses are coded on different scales. We have standardized these measures by averaging the two questions asked in 1995 and 1998, and converting all measures to a 1-to-10 scale.

${ }^{31}$ Our results differ somewhat from Ameriks and Zeldes (2000), who find a significant effect of age on ownership but not on the risky share, using pooled data from the 1989, 1992, and 1995 SCFs. Their regressions, like ours, include time dummies, but otherwise their specification differs from ours in a number of other respects (one age term, no controls for household wealth or other characteristics, OLS regressions). Running such regressions on our data yields similar results.

${ }^{32}$ For example, in the $1998 \mathrm{SCF}$, only $12 \%$ of households in the bottom $25 \%$ of the income distribution were eligible to participate in employer-sponsored retirement accounts, compared to $42 \%$ of households overall. 
Married couples and female-headed households have a higher probability of owning risky financial assets, compared to unmarried men. The result for women differs from previous studies, which have suggested that women tend to have less risky portfolios than men (see, for example, Jianakoplos and Bernasek, 1998). While this is a subject of open investigation, it should be noted that our specification controls for a number of factors that differ between women and men and contribute to observed portfolio differences between them (e.g. income, stated risk preference, etc). ${ }^{33}$ Conceivably, women may even favor risky investments, compared to male counterparts, since their longer life expectancies imply longer investment horizons. Nonetheless, our finding on gender is somewhat sensitive to changes in specification; this suggests a need for caution in interpreting the result.

A final result of interest is the significantly lower ownership of risky assets among nonwhite and Hispanic households. Again, this may reflect greater income uncertainty or unequal access to credit, which could tilt the portfolio away from risky assets. Family background may also play some role here; for example, using data from the Panel Study of Income Dynamics, Chiteji and Stafford (1999) found that about 44 percent of young families whose parents owned stock held equities themselves, compared to 24 percent of those whose parents did not. Alternatively, it is possible that the lower incidence of stockownership among minorities reflects some degree of differential treatment in the financial services industry (Loury 1998).

Results for the selection model using total risky assets are presented in Table 9. Most results are qualitatively quite similar to those for risky financial assets. The findings on age are somewhat weaker: Ownership drops off in the 65+ age group, as does the risky share, although both results are significant at a $10 \%$ level only. Both ownership and the risky share are strongly related to wealth. One notable difference from the financial asset model is that, whereas risky assets were downplayed in the financial portfolios of the self-employed, this group was more

\footnotetext{
${ }^{33}$ Descriptive statistics from the SCF show the expected male/female gap: in 1998, about $33 \%$ of female-headed households owned stock in some form, compared to $42 \%$ of households headed by unmarried men and $58 \%$ of married couples. Nonetheless, female-headed households were considerably more likely to express unwillingness to take financial risks: well over one-half of female-headed households said they took no risks in their savings and investments, versus about one-third of male-headed and married-couple households. This difference in self-reported risk preference contributes to, but does not explain away, the different econometric result on gender.
} 
likely to own risky assets overall (i.e. due to their business interests) and had a higher share of their assets in risky forms. This suggests that the safety of their financial portfolios may be hedging the risks associated with their other assets, although only partially.

\section{Multivariate probit model}

While decisions about risky assets are a central aspect of portfolio decisions, joint decisions about holding different assets and liabilities are also of interest. ${ }^{34}$ In particular, households make decisions not only about financial assets, but also about home ownership and business interests. Also, their decisions about asset holdings may be taken with borrowing considerations in mind (Paxson, 1990; Engen and Gale, 1997).

To investigate joint decisions, we take advantage of recent advances in simulation methods and estimate a multivariate probit model of portfolio choice. Under the multivariate probit, we observe a $0 / 1$ variable for whether a given household holds each asset or liability. We can also allow for correlation across the error terms resulting from unobservable householdspecific factors. If the error terms are uncorrelated across assets, this results in a series of standard single-equation probits. However, if the error terms are correlated, it is preferable to model the asset-holding decisions jointly, as can be done with the multivariate probit.

The model we estimate includes four categories of assets: stock-based financial assets, safe investment assets, the primary residence, and business interests. ${ }^{35}$ We also include one liability, consumer debt, due to interest in the puzzle of its widespread extent. ${ }^{36}$ The explanatory variables are largely as before, although here the log of net worth is used as the measure of wealth. The model is estimated using Geweke, Hajivassiliou, and Keane's simulation method to approximate the multivariate normal distribution (Greene 1997). ${ }^{37}$ Due to the computational

\footnotetext{
${ }^{34}$ Previous studies examining joint decisions include King and Leape (1998), and Dicks-Mireaux and King (1983).

${ }^{35}$ As before, stock-based financial assets include directly-held stock, and shares held through mutual funds, retirement accounts, and trusts and managed assets. Safe investment assets include safe financial assets other than liquid accounts: certificates of deposit, cash-value life insurance, savings bonds, other bonds, and non-stock amounts held through mutual funds, retirement accounts, and trusts and managed assets.

${ }^{36}$ Here consumer debt includes credit card balances outstanding after the past month's payments, plus non-vehicle installment loans.

${ }^{37}$ See also the November 1994 issue of Review of Economics and Statistics.
} 
intensity of the model, we use data from the 1995 SCF only. To our knowledge, this is the first application of the multivariate probit model to the analysis of portfolio choice.

Results from the model are presented in Table 10.

- $\underline{\text { Age. }}$ The multivariate results show rather mixed effects of age on household portfolios. Age had no significant effect on the probability of having stock-based assets, nor on the probability of having safe investment assetts. Under- 35 households were significantly less likely to own a home than households in the 35-54 age range; this probably reflects the need to accumulate assets for a down payment, and/or the lower attractiveness of homeownership to the young. Our results do not show a tendency for homeownership to decline with age: the coefficient for the $65+$ range is positive and significant at the $10 \%$ level, although it is smaller than the coefficient for the 55-64 range. While this finding is interesting for the debate about whether the elderly spend down their housing wealth, it is unclear whether it should be interpreted literally, especially given that studies using panel data show a different result. ${ }^{38}$ We also find that business ownership drops off significantly in the $65+$ age group, consistent with other research and suggesting that older households sell off business assets when they scale back work hours. The probability of having consumer debt drops off considerably in the older age ranges. However, the use of consumer debt is not higher in the younger age range, as might be predicted from a lifecycle perspective. Conceivably, this may not be the optimal choice of younger households, as some may be credit constrained. For example, the SCF asks whether households had been turned down for credit in the past five years, or had not applied for credit in anticipation of being rejected. By this definition, in 1995, some 39 percent of under-35 households would be classified as liquidity constrained, compared to 22 percent of households overall. ${ }^{39}$

- Net worth. Not surprisingly, higher net worth raises the probability of having all four types of assets, while it lowers the probability of having consumer debt. However, the same size increase in wealth, other things being equal, contributes more to the probability of stock

\footnotetext{
${ }^{38}$ See Hurd (1999), and Kennickell and Starr-McCluer (1997). Note also that our use of $65+$ as the oldest age group may obscure a drop-off among the older old.

${ }^{39}$ As in other studies using these variables, the 'liquidity constrained' include households turned down for credit, who did not eventually get the amount they requested by reapplying, and those
} 
ownership than ownership of safe investment assets. For example, for an otherwise typical household, an increase in net worth from about $\$ 9,000$ to $\$ 59,000$ - equivalent to moving from the $25^{\text {th }}$ to the $50^{\text {th }}$ percentiles of the wealth distribution --increases the estimated probability of stock ownership from $28 \%$ to $36 \%$, but increases the probability of owning safe investment assets from $65 \%$ to $70 \%$. Both the higher probability of owning safe investment assets and the larger increase in the probability of stock ownership are consistent with the view that stocks should be added to a portfolio after a buffer of safe investment assets is in place. ${ }^{40}$

- Income. As might be expected, higher income raises the probability of owning stock-based assets; it also raises the probability of homeownership. However, it has no significant effect on the probability of owning safe investment assets or a business, and it has a negative effect on the probability of having consumer debt.

- Education. College-educated households have a significantly higher probability of owning stock-based assets, other things being equal. As discussed previously, this may be a byproduct of this group's lower income risk, which may make them feel more comfortable investing in stock. But it may also reflect some informational advantage characteristic of this group. Some evidence here is that, ceteris paribus, college-educated households are also less likely to have consumer debt, which is often at high interest rates and, unlike mortgage and home-equity borrowing, is not tax-advantaged; this may reflect differential ability to gather and use financial information. ${ }^{41}$

- Other demographic characteristics. Married-couple households are more likely to own stockbased assets, safe investment assets, and their own home; they are also more likely to have consumer debt. As above, we find that female-headed households are more likely to own stock-based assets than households headed by single males. But interestingly, female-headed household are significantly less likely to own a business, suggesting that any greater

who did not apply for credit because they thought they would be turned down. See, for example, Cox and Jappelli (1993).

${ }^{40}$ The same increase in net worth for the otherwise typical household increases the estimated probability of homeownership from $86 \%$ to $93 \%$ and of business ownership from $4 \%$ to $9 \%$, while it decreases the probability of holding consumer debt from $58 \%$ to $51 \%$.

${ }^{41}$ See, for example, Maki's (1996) work on household response to the elimination of the deductibility of interest on consumer debt. 
willingness to take financial risk that they may have could reflect less need to hedge against business risks. Again, we find nonwhite households less likely to own stocks, ceteris paribus; they are also less likely to own homes and more likely to have consumer debt. The lower probability of homeownership may at least partially reflect unequal access to mortgage debt (see Ladd, 1998).

- Correlation across equations. As shown at the bottom of Table 10, the estimates of the $\rho$ 's from the multivariate probit are significant for many pairs of equations, rejecting the null hypothesis that the disturbance terms are uncorrelated. Since our models include a measure of risk preference, unobserved variation would be expected to reflect other factors, such as differences in income expectations, priors about asset returns, time preferences, and family background. The estimated correlations are positive and significant at a 5\% level for stockbased assets and safe investment assets, and for homeownership and consumer debt; the correlation is positive and significant at a $10 \%$ level for safe investment assets and home ownership. While a positive correlation between the various asset categories is perhaps not surprising, the positive correlation between homeownership and consumer debt is more puzzling, given that most homeowners have access to lower-cost sources of borrowing. Perhaps those households more likely to own homes and have consumer debt than their observed characteristics would predict also have higher income expectations or higher discount rates. In contrast, the correlation is negative and significant for home and business ownership. Although the majority of business owners are also homeowners, it is important to remember that these equations control for net worth and self-employment status. Thus, one possible interpretation is that, other things equal, business owners may be less willing to undertake the additional responsibilities associated with home ownership.

\section{Conclusions and policy implications}

Our econometric results highlight the important effects of age and wealth on the structure of household portfolios. Age has significant effects on the ownership of risky assets, although evidence of effects on the risky share is more mixed. Both ownership of risky assets and the risky share clearly rise with wealth, whether financial or total assets are considered. Factors associated with income risk and labor supply flexibility also have expected effects: for example, 
the financial portfolios of self-employed and retired households tend to be relatively safe, while college-educated households tend to take more risk. Our findings also suggest that differences across assets and across households in information and entry costs help explain the fairly simple and safe structure of the typical household portfolio in the U.S.. In particular, investing in stockbased assets requires time and ability to process financial information, with minimum investments often required for non-retirement accounts. For a sizable share of households, these features represent important deterrents to equity ownership. Nonetheless, as our descriptive statistics and econometric work show, this picture has changed considerably in recent years, as the ease of investing through employer-sponsored retirement accounts has put equity ownership within reach for a much broader segment of the population.

Our results suggest a number of policy implications. First, the finding about information/entry costs suggests that public and private policies affecting such costs are likely to have appreciable effects. The shift toward employer-sponsored retirement accounts has certainly been of major importance in this regard, converting to stockowners quite a lot of those who "should have" owned stock - based on income risk, labor supply flexibility, time to retirement, etc. - but did not due to information and entry costs. ${ }^{42}$ However, it is also true that, even with low-cost access, some of those who do not currently own stock probably "should not" on these grounds, and need to be so advised. This suggests that, for example, any self-directed investment component of Social Security would require a strong informational component. This is all the more true because, in the future, financial markets may not be as beneficent as they have been in the past 10 or 20 years.

Second, with age often a significant factor in portfolio choice, an important policy question concerns possible effects of demographic shifts on asset markets. For example, some have argued that the movement of the large "baby boom" cohort into pre-retirement saving years fueled the 1990s boom in stock prices, just as their movement into nesting years may have fueled

\footnotetext{
${ }^{42}$ Indeed, some evidence suggests that investing in equities through employer-sponsored accounts may increase equity ownership outside of such accounts (Weisbenner 1999). Also, the shift to defined-contribution pensions has been accompanied by a general increase in workplace financial education, as discussed in Bayer, Bernheim, and Scholz (1996) and Bernheim and Garrett (1996).
} 
an earlier boom in housing prices. ${ }^{43}$ Of course, it is tricky to draw inferences for asset markets directly from household behavior. Theory does not suggest that lifecycle aspects of portfolio choice would be fixed; rather, they would reflect expectations of a number of variables - real wages, unemployment, asset returns, the generosity of public pensions, etc. - that themselves may be influenced by demographics. This highlights the need for a general-equilibrium approach to analyzing asset-market effects of population aging. Understanding such effects would provide valuable insight for debates about retirement preparedness and retirement policy.

Finally, with portfolios differing considerably across the distribution of income or wealth, changes in key macro variables, such as interest rates or stock prices, may have quite different effects on households of different types. For example, an increase in interest rates both raises households' debt payments, and also raises their income from interest-bearing assets; however, because debt holdings tend to decline with wealth, the higher a household is on the wealth scale, the more likely it is that the income effect will dominate the effect on debt payments.

Differential effects like this may have important implications for the behavior of aggregate consumption. Notably, if marginal propensities to consume vary across the wealth distribution, an increase in the value of a widely-held asset (like housing) might have a much stronger effect on consumption than an increase for an asset held mostly by the rich (like stock). ${ }^{44}$ This suggests that we may gain a richer view of consumption and saving by understanding household portfolios.

\footnotetext{
${ }^{43}$ Poterba (1998) investigates effects of population aging on stock and bond prices. For analysis of housing-market effects, see Mankiw and Weil (1989), McFadden (1994), and Hoynes and McFadden (1997).

${ }^{44}$ Dynan, Skinner, and Zeldes (1999) present evidence that marginal propensities to consume vary with permanent income. On wealth effects on spending, see Poterba and Samwick (1995); and Starr-McCluer (2000).
} 
Table 1. The Level and Composition of Household Wealth: Aggregate Data

\begin{tabular}{|c|c|c|c|c|c|}
\hline & 1983 & 1989 & 1992 & 1995 & 1998 \\
\hline Avg. net worth per household (th. of '98 \$) & 209.2 & 263.1 & 261.7 & 282.4 & 345.9 \\
\hline \multicolumn{6}{|l|}{ Assets and liabilities as \% of total assets: } \\
\hline Financial assets & 44.5 & 48.8 & 53.0 & 56.3 & 60.8 \\
\hline Liquid assets $^{1}$ & 3.5 & 3.6 & 3.5 & 3.4 & 3.4 \\
\hline Time and savings deposits & 12.4 & 10.9 & 9.1 & 7.7 & 7.1 \\
\hline Savings bonds & 0.6 & 0.5 & 0.6 & 0.6 & 0.5 \\
\hline Other bonds & 2.7 & 3.7 & 4.3 & 3.8 & 2.5 \\
\hline Corporate equity $^{2}$ & 6.7 & 8.1 & 10.4 & 12.4 & 14.3 \\
\hline Mutual funds & 0.7 & 2.0 & 2.7 & 4.0 & 5.9 \\
\hline Pension reserves ${ }^{3}$ & 12.0 & 14.4 & 16.4 & 18.7 & 22.0 \\
\hline Life insurance & 1.9 & 1.6 & 1.8 & 1.8 & 1.7 \\
\hline Bank personal trusts & 2.5 & 2.4 & 2.6 & 2.6 & 2.4 \\
\hline Other financial & 1.7 & 1.5 & 1.5 & 1.3 & 1.1 \\
\hline Nonfinancial assets & 55.5 & 51.3 & 47.0 & 43.8 & 39.2 \\
\hline Residential property ${ }^{4}$ & 28.0 & 29.2 & 27.1 & 24.7 & 22.4 \\
\hline Noncorporate business ${ }^{5}$ & 19.1 & 14.1 & 12.1 & 11.6 & 10.4 \\
\hline Durable goods & 8.5 & 8.0 & 7.8 & 7.5 & 6.3 \\
\hline Debts & 13.0 & 14.1 & 14.6 & 15.0 & 14.1 \\
\hline Mortgage & 8.5 & 10.0 & 10.8 & 10.5 & 9.8 \\
\hline Consumer debt & 3.4 & 3.6 & 3.1 & 3.6 & 3.2 \\
\hline Other debt & 1.1 & 0.6 & 0.6 & 0.8 & 1.0 \\
\hline \multicolumn{6}{|l|}{ Memo items: } \\
\hline$\overline{\text { Equity share of financial assets }}{ }^{6}$ & 14.6 & 19.1 & 23.1 & 28.2 & 34.6 \\
\hline $\begin{array}{l}\text { Equity in residential property as } \% \text { of net } \\
\text { Worth }\end{array}$ & 22.5 & 22.4 & 19.2 & 16.7 & 14.6 \\
\hline Mortgage debt as $\%$ of total debt & 65.1 & 70.6 & 74.2 & 70.4 & 70.0 \\
\hline $\begin{array}{l}\text { Mortgage debt as } \% \text { of value of residential } \\
\text { Property }\end{array}$ & 30.3 & 34.2 & 39.8 & 42.6 & 43.9 \\
\hline
\end{tabular}

Source: Authors' computations, Flow of Funds Accounts, year-end values.

Notes:

${ }^{1}$ Includes currency, checkable deposits, money market accounts, foreign accounts, and security credit.

2 Includes equity in closely held businesses.

${ }^{3}$ Largely employer sponsored plans; most IRA and Keoghs are included in the items in which they are invested, although those held in individual annuities at life insurance companies are included here.

${ }_{5}^{4} 1-4$ family residential property.

${ }^{5}$ Equity in noncorporate businesses only.

${ }^{6}$ Published figure for the FFA household sector (i.e. includes nonprofits). 
Table 2. The Level and Composition of Household Wealth: Survey Data

\begin{tabular}{|c|c|c|c|c|c|}
\hline & 1983 & 1989 & 1992 & 1995 & 1998 \\
\hline \multicolumn{6}{|l|}{ Level of net worth } \\
\hline Median (th '98 \$) & 56.9 & 59.0 & 55.8 & 59.4 & 71.1 \\
\hline Average (th '98 \$) & 194.6 & 233.8 & 211.1 & 220.4 & 281.1 \\
\hline SCF average as $\%$ of FFA & 93.0 & 88.9 & 80.7 & 78.0 & 81.3 \\
\hline \multicolumn{6}{|l|}{ Assets and liabilities as \% of total } \\
\hline \multicolumn{6}{|l|}{ assets } \\
\hline Financial assets & 29.4 & 28.9 & 30.6 & 35.2 & 40.0 \\
\hline Liquid accounts & 5.0 & 5.7 & 5.4 & 5.1 & 4.6 \\
\hline Certificates of deposit & 3.3 & 3.0 & 2.5 & 2.1 & 1.7 \\
\hline Savings bonds & 0.2 & 0.4 & 0.4 & 0.5 & 0.3 \\
\hline Other bonds & 3.1 & 3.0 & 2.6 & 2.3 & 1.7 \\
\hline Stocks & 7.9 & 4.5 & 5.1 & 5.7 & 9.2 \\
\hline Mutual funds & 0.9 & 1.6 & 2.4 & 4.7 & 5.0 \\
\hline Retirement accounts & 3.8 & 5.5 & 7.5 & 8.8 & 10.6 \\
\hline Cash-value life insurance & 2.4 & 1.8 & 1.9 & 2.7 & 2.6 \\
\hline Trusts \& other managed assets & 2.6 & 1.9 & 1.7 & 2.2 & 3.6 \\
\hline Other financial & 0.2 & 1.4 & 1.2 & 1.2 & 0.7 \\
\hline Memo: All equity & 9.5 & 8.3 & 10.4 & 13.8 & 21.7 \\
\hline Nonfinancial assets & 70.6 & 71.1 & 69.4 & 64.8 & 60.0 \\
\hline Primary residence & 31.6 & 31.2 & 31.7 & 30.1 & 27.7 \\
\hline Investment real estate & 15.3 & 16.2 & 14.9 & 11.4 & 10.6 \\
\hline Business equity & 19.3 & 18.2 & 17.8 & 17.3 & 16.9 \\
\hline Other nonfinancial & 4.3 & 5.5 & 5.0 & 6.0 & 4.8 \\
\hline Debts & 12.9 & 15.3 & 16.2 & 16.1 & 15.4 \\
\hline Mortgage \& home equity & 7.4 & 8.4 & 10.4 & 10.8 & 10.3 \\
\hline Loans for investment real estate & 2.7 & 4.0 & 3.2 & 2.4 & 2.1 \\
\hline Credit card balances & 0.2 & 0.3 & 0.5 & 0.6 & 0.5 \\
\hline Other debt & 2.6 & 2.6 & 2.1 & 2.3 & 2.4 \\
\hline \multicolumn{6}{|l|}{ Memo items: } \\
\hline$\overline{\text { Equity share of financial assets }}$ & n.a. & 28.6 & 34.1 & 39.1 & 54.4 \\
\hline $\begin{array}{l}\text { Equity in primary residence as } \% \\
\text { of net worth }\end{array}$ & 27.9 & 26.9 & 25.4 & 23.0 & 20.6 \\
\hline Median share for homeowners & 59.6 & 58.4 & 54.1 & 49.3 & 43.4 \\
\hline Mort \& HE debt as $\%$ of total debt & 57.2 & 54.8 & 64.2 & 67.4 & 66.8 \\
\hline Mort \& HE debt as $\%$ of home value & 23.3 & 26.9 & 32.8 & 35.9 & 37.1 \\
\hline
\end{tabular}

Source: Surveys of Consumer Finances, weighted data.

$\underline{\text { Notes }}$

Financial assets

Liquid accounts

Checking accounts, savings accounts, money market deposit accounts, money market

CDs

Savings bonds mutual funds, and call accounts at brokerages

Certificates of deposit (may be short- or long-term)

U.S. savings bonds 
Notes to Table 2 (continued):

Other bonds

Stocks

Mutual funds

Retirement accounts

Cash-value life ins.

Trusts and managed

assets

Other financial

Memo: Equity

Nonfinancial assets

Primary residence

Investment real estate

Business equity

Other nonfin.

\section{Debts}

Mortgage \& home equity

Inv. real estate

Credit card

balances

Other debt
Federal government bonds other than U.S. savings bonds, bonds issued by state and local governments, corporate bonds, mortgage-backed bonds, foreign bonds, and other types of bonds.

Directly-held stock in publicly traded corporations.

Directly-held shares in all types of mutual funds, excluding money market.

Includes both individual accounts (IRA and Keogh) and employer-sponsored thrift-type retirement accounts.

Surrender value of life insurance policies that build up a cash value.

Equity interests in trusts, annuities, and managed investment accounts.

Royalties; futures contracts; oil and gas leases; future proceeds from a lawsuit, estate, or lottery; deferred compensation, etc.

Includes directly-held stock, and shares held through mutual funds, retirement accounts, and trusts and other managed assets.

May be single-family or other type of home (mobile home, apartment, town house, etc). Includes residential and nonresidential property not owned through a business.

Net equity in all types of privately-owned businesses, farms or ranches, professional practices, and partnerships. The household may have an active management role in the business, or may only invest in the business.

Includes all standard passenger vehicles (cars, trucks, vans, minivans, jeeps, etc) not owned by a business; all other types of personal-use vehicles (motor homes, recreational vehicles, planes, boats, motorcycles, etc); and miscellaneous nonfinancial assets such as artwork, antiques, jewelry, furniture, and valuable collections (coin, stamp, etc).

All borrowing secured by the primary residence, including first and second mortgages and home equity loans and lines of credit.

All outstanding loans or mortgages on property other than the primary residence.

Balances outstanding after the last month's payment on general-purpose Mastercard/Visa) and other types of cards (store, gas, travel and entertainment, airline, etc).

Includes home improvement loans, student loans, vehicle loans, other installment loans, lines of credit other than home equity, and loans against pensions and life insurance policies. 
Table 3. Ownership of assets and liabilities

\begin{tabular}{|l|rrrrr|}
\hline & \multicolumn{3}{c}{ Percent of households with holdings } \\
\hline Net worth $>0$ & 1983 & 1989 & 1992 & 1995 & 1998 \\
& 92.1 & 88.7 & 89.5 & 89.9 & 89.5 \\
Financial assets & & & & & \\
Liquid accounts & 89.7 & 88.6 & 90.1 & 90.6 & 92.9 \\
Certificates of deposit & 87.4 & 85.3 & 86.9 & 87.0 & 90.5 \\
Savings bonds & 20.1 & 19.9 & 16.7 & 14.3 & 15.3 \\
Other bonds & 20.2 & 23.9 & 22.3 & 22.8 & 19.3 \\
Stocks & 4.2 & 5.7 & 4.3 & 3.1 & 3.0 \\
Mutual funds & 19.1 & 16.8 & 17.0 & 15.2 & 19.2 \\
Retirement accounts & 4.5 & 7.2 & 10.4 & 12.3 & 16.5 \\
Cash-value life insurance & 30.8 & 35.6 & 38.1 & 43.0 & 48.0 \\
Trusts \& other managed assets & 34.1 & 35.5 & 34.9 & 32.0 & 29.6 \\
Other financial & 4.0 & 3.6 & 4.0 & 3.9 & 6.0 \\
Memo: Any equity & 1.6 & 13.8 & 10.8 & 11.1 & 9.4 \\
& $n . a$. & 31.6 & 36.7 & 40.4 & 48.9 \\
Nonfinancial assets & & & & & \\
Primary residence & 90.3 & 89.2 & 90.8 & 90.9 & 89.9 \\
Investment real estate & 63.4 & 63.9 & 63.9 & 64.7 & 66.3 \\
Business equity & 21.0 & 20.2 & 19.3 & 18.0 & 18.6 \\
Other nonfinancial & 14.4 & 11.6 & 11.9 & 11.1 & 11.5 \\
& 7.4 & 12.4 & 8.3 & 9.0 & 8.5 \\
Debts & & & & & \\
Mortgage \& home equity & 70.0 & 72.7 & 73.4 & 74.7 & 74.3 \\
Loans for investment real estate & 36.9 & 39.5 & 39.1 & 41.0 & 43.1 \\
Credit card balances & 8.2 & 7.3 & 7.8 & 6.4 & 6.6 \\
Other debt & 37.0 & 39.7 & 43.7 & 47.3 & 44.1 \\
& 53.8 & 56.0 & 54.0 & 54.3 & 48.5 \\
\hline
\end{tabular}

Source: Surveys of Consumer Finances, weighted data. For detailed definitions, see notes to Table 2. 


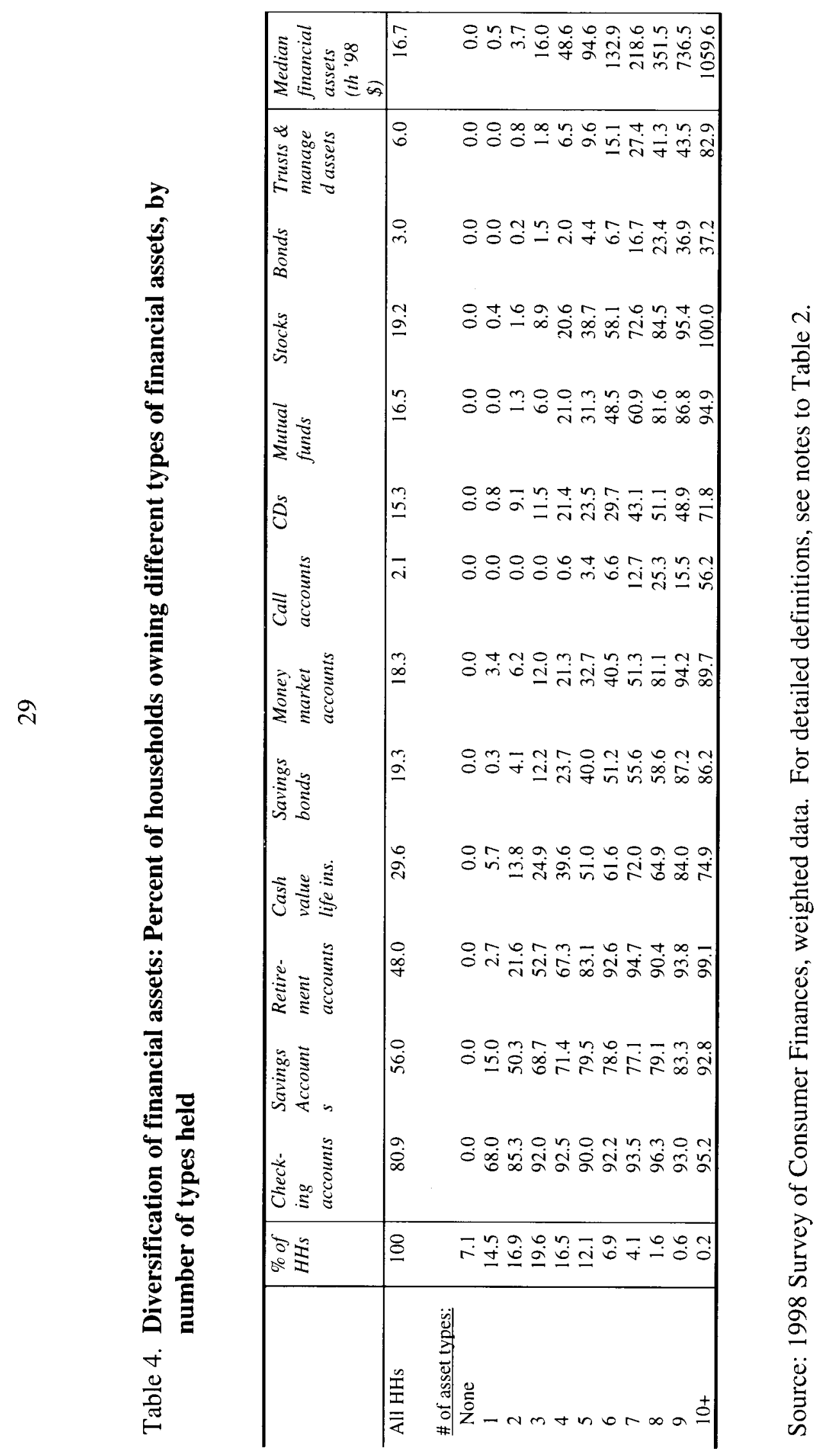




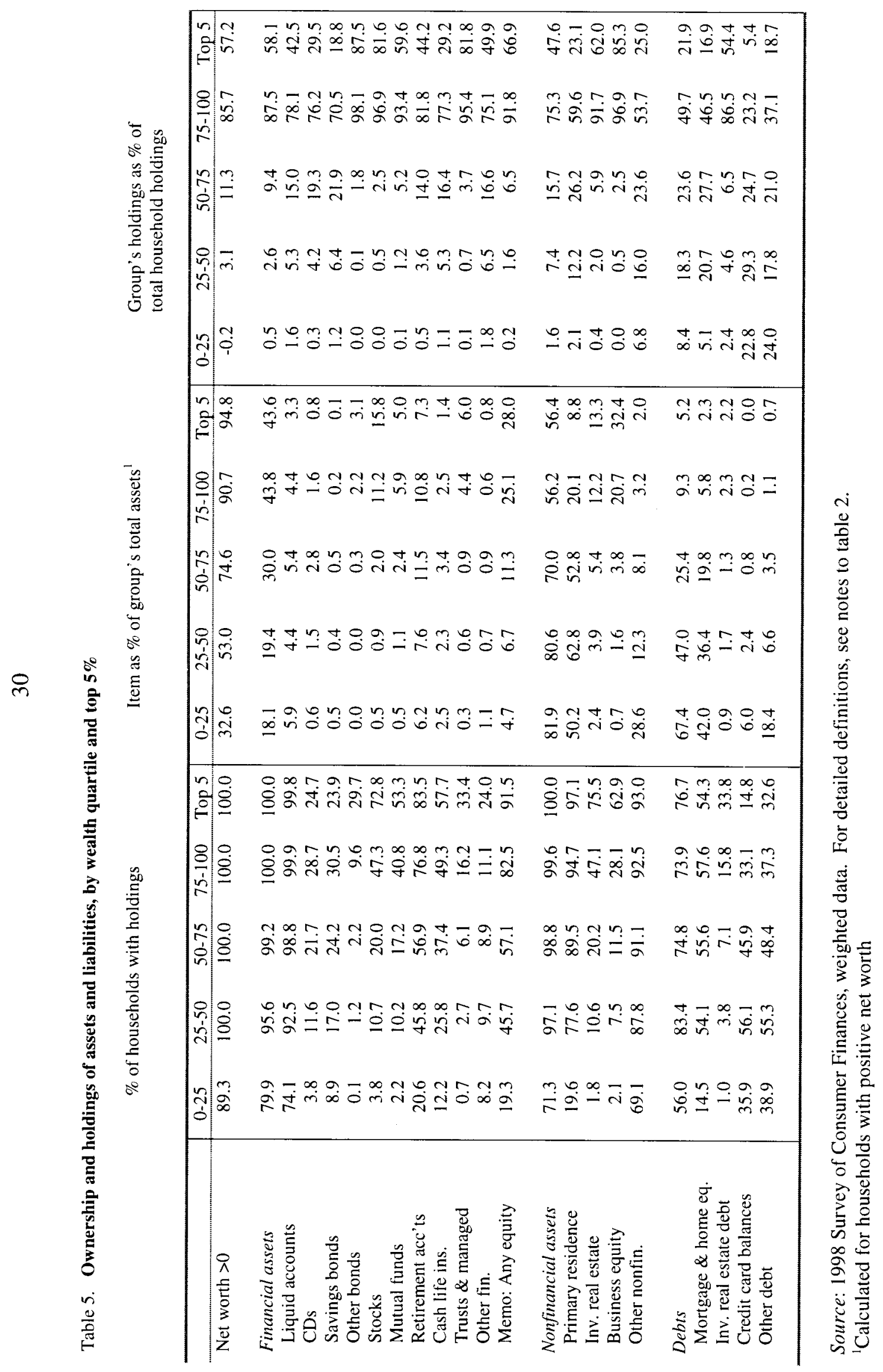




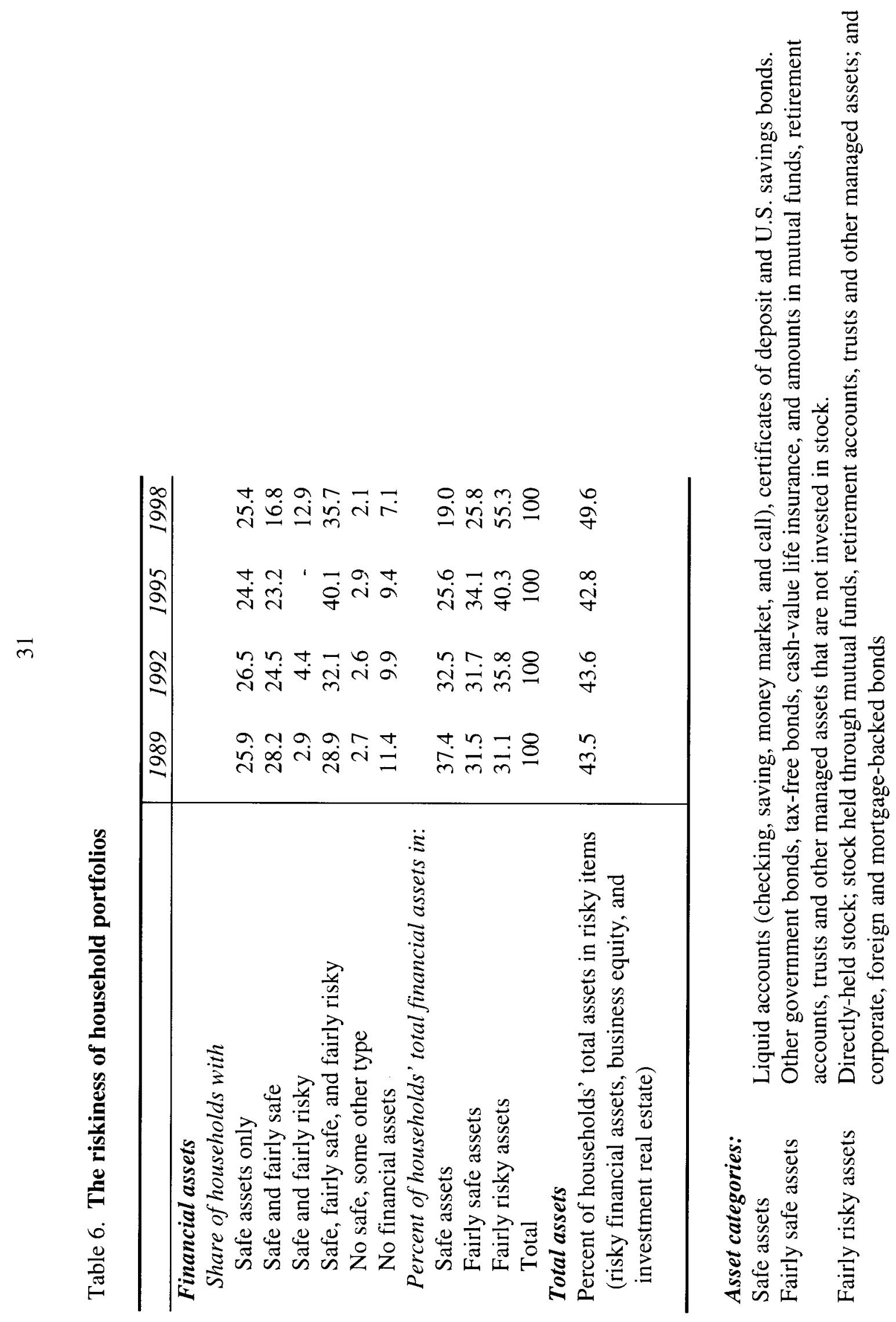




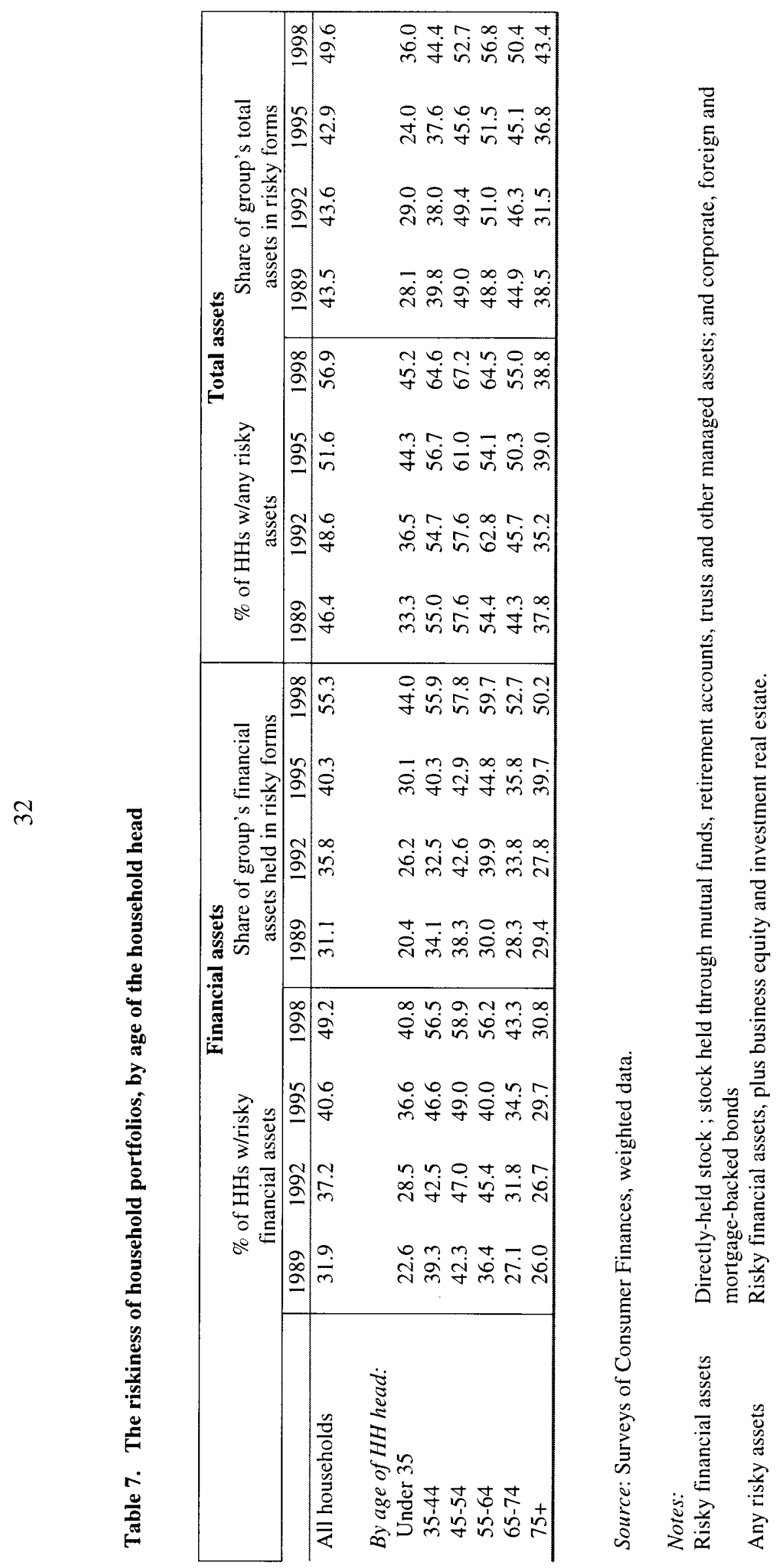




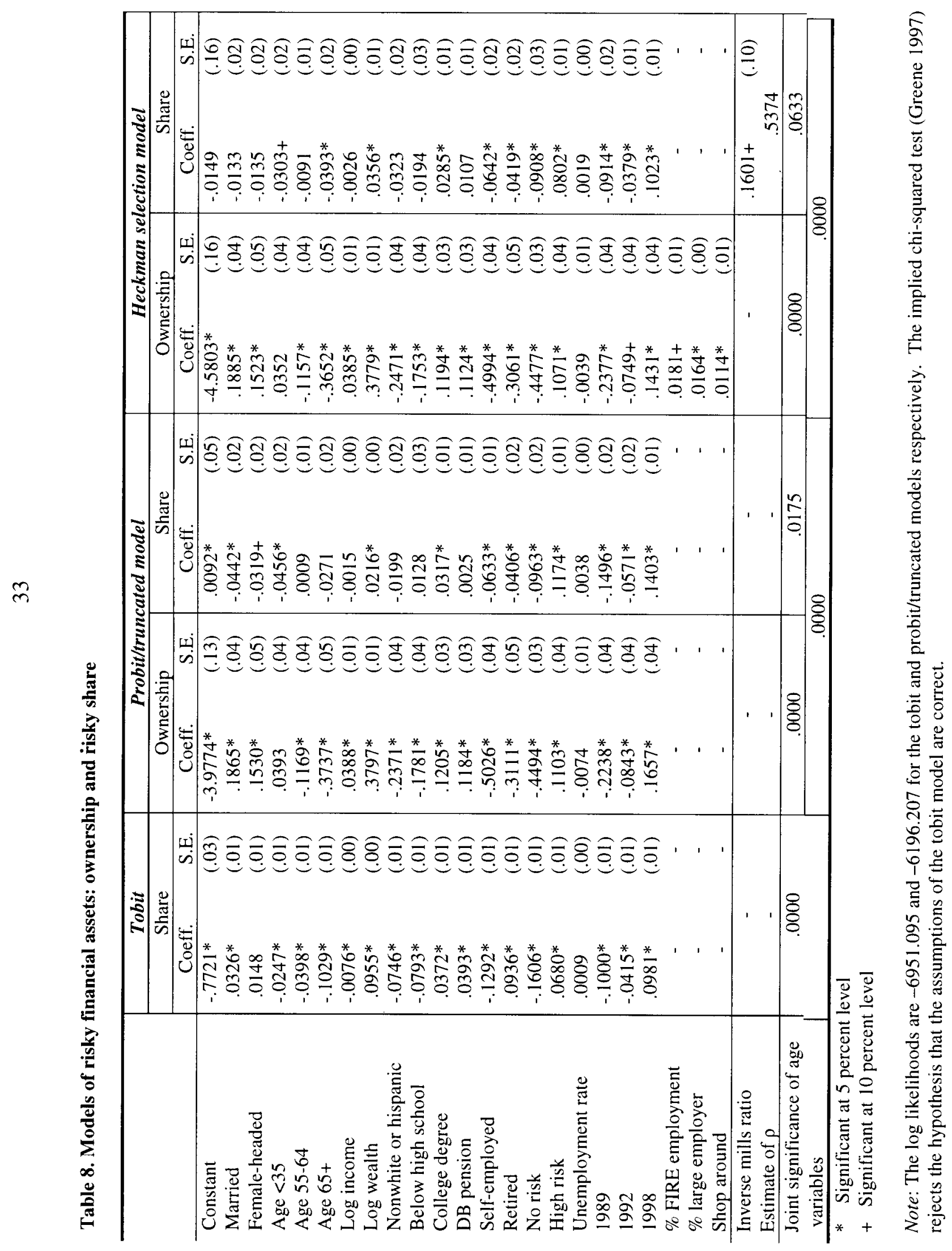


m

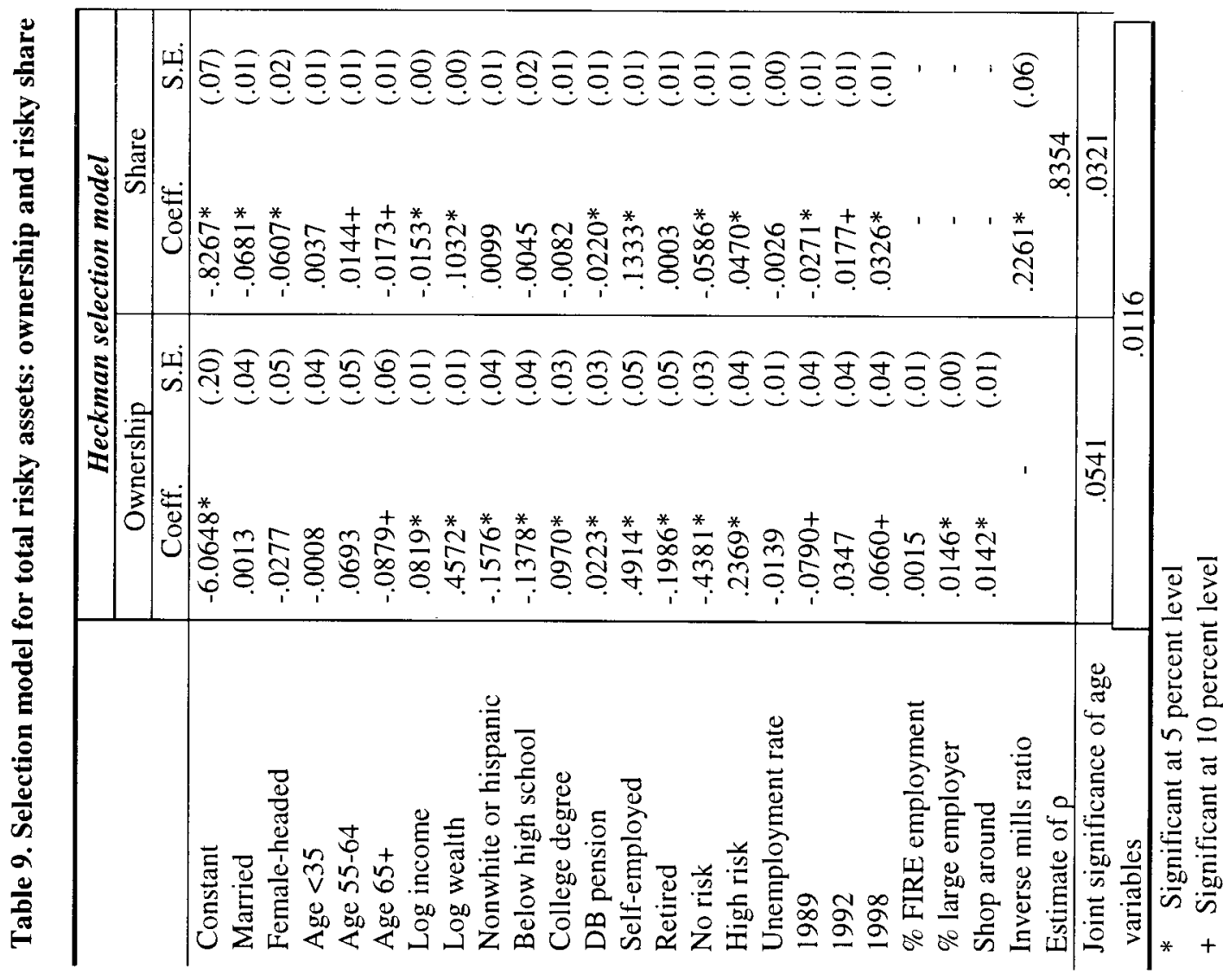




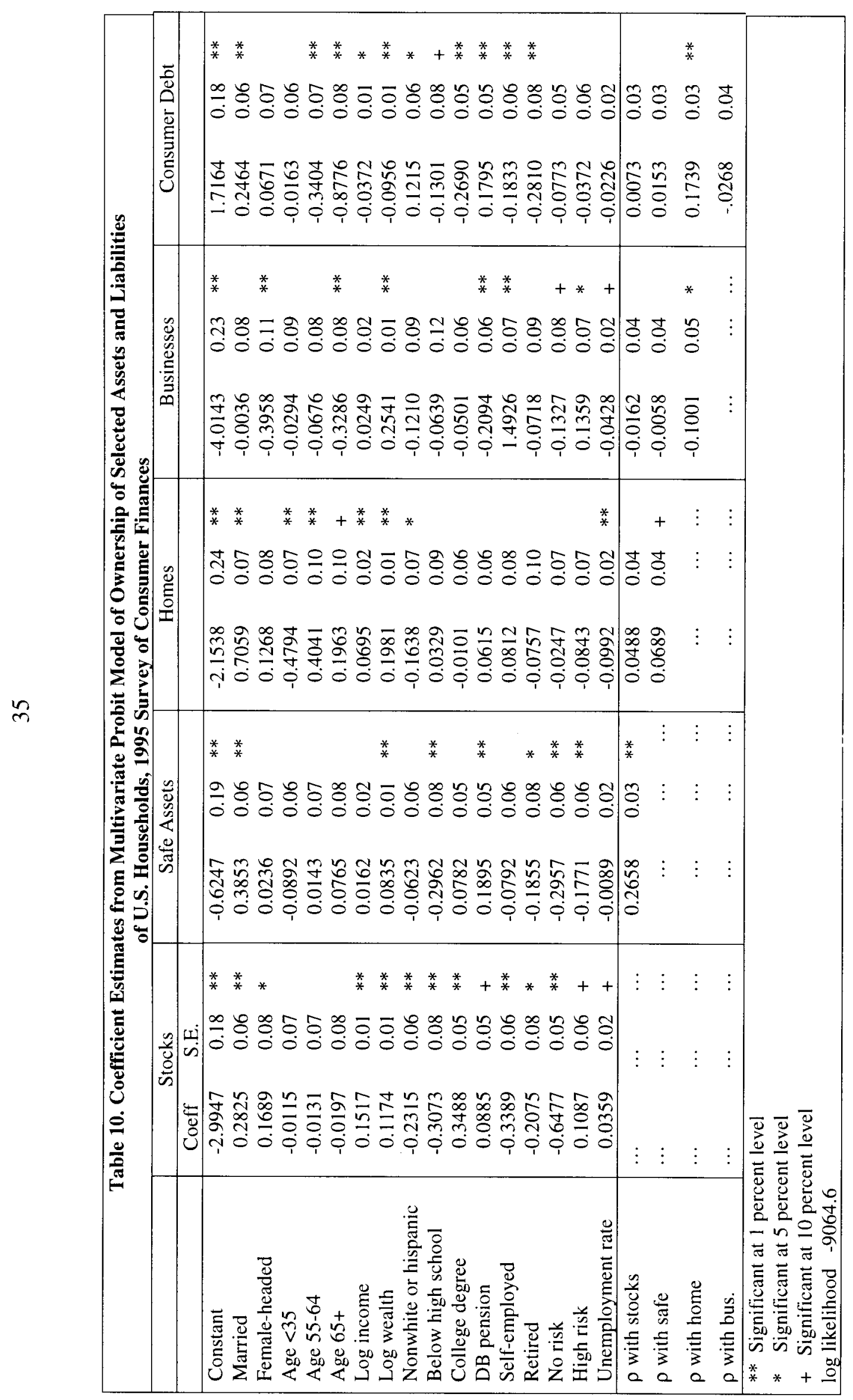


Figure 1. Asset returns and macro variables, 1983-98
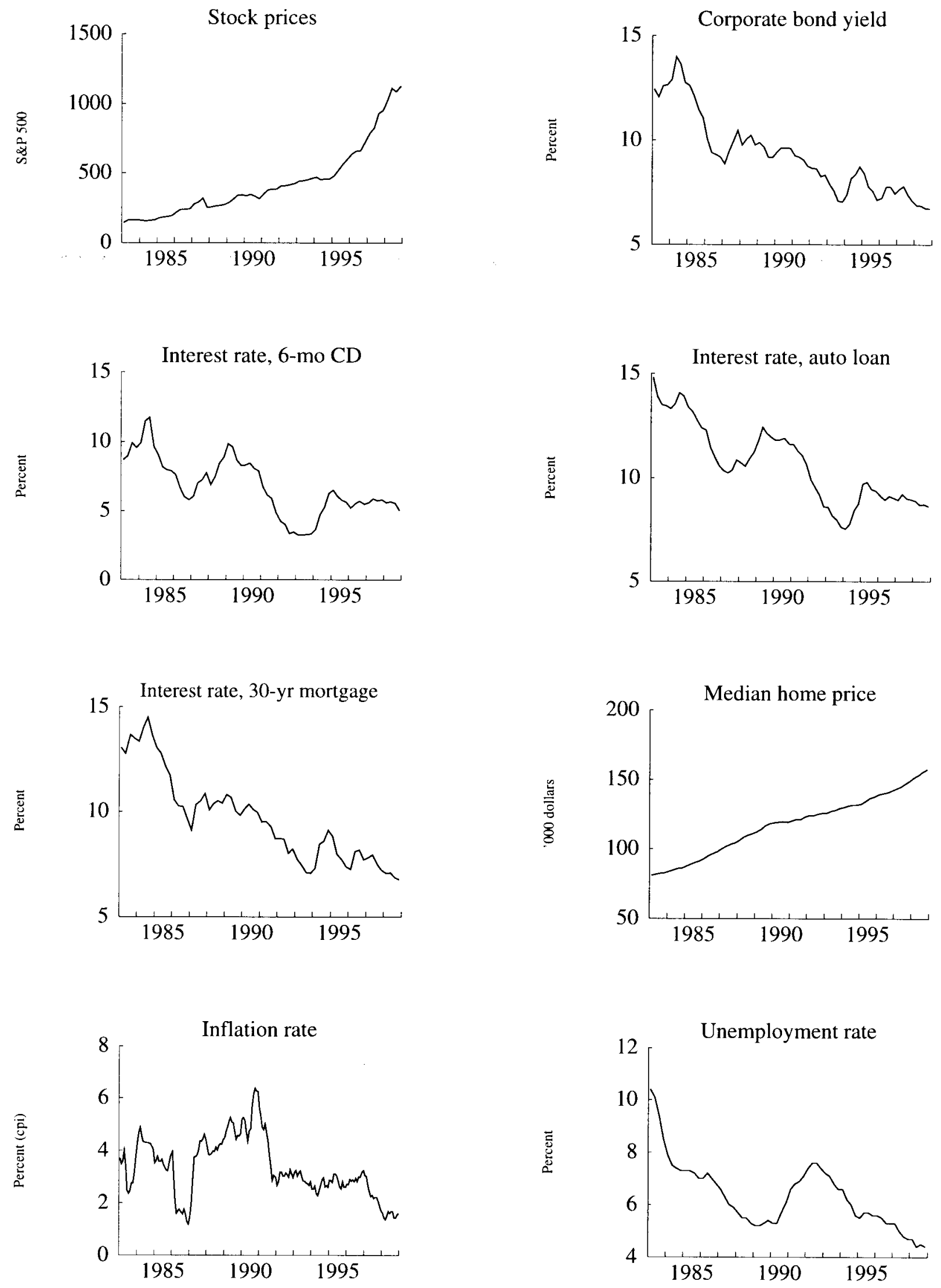
Appendix Table A. Characteristics of households owning equity, 1989 and 1992

\begin{tabular}{|l|r|r|}
\hline & $\mathbf{1 9 8 9}$ & $\mathbf{1 9 9 8}$ \\
\hline $\begin{array}{l}\text { Characteristics of households } \\
\text { owning equity: }\end{array}$ & & \\
\hline & & \\
\hline Average age of HH head (years) & 48.9 & 47.9 \\
\hline Education of HH head (\%): & 7.7 & 8.4 \\
\hline Below high school & 45.3 & 44.7 \\
\hline High school diploma & 47.0 & 46.8 \\
\hline College degree & 58.3 & 53.1 \\
\hline Median income (th '98 \$) & 184.3 & 156.1 \\
\hline Median net worth (th '98 \$) & 14.6 & 4.5 \\
\hline $\begin{array}{l}\text { \% of equity owners owning shares in } \\
\text { one company only (\%) }\end{array}$ & 65.5 & 66.9 \\
\hline $\begin{array}{l}\text { Percent of total household equity } \\
\text { held by the top 5\% of the } \\
\text { wealth distribution }\end{array}$ & & \\
\hline & 29.4 & 50.1 \\
\hline Millions of households & & \\
\hline
\end{tabular}




\section{References}

Ameriks, John and Stephen P. Zeldes (2000). "How Do Household Portfolio Shares Vary with Age?" Paper presented at the conference on "Household Financial Decision-Making," Wharton School, University of Pennsylvania (March).

Antoniewicz, Rochelle (1996). "A Comparison of the Household Sector from the Flow of Funds Accounts and the Survey of Consumer Finances." Federal Reserve Board Discussion Paper \# 96-26.

Ausubel, Lawrence (1991). "The Failure of Competition in the Credit Card Market," American Economic Review, Vol. 81, No. 1, pp. 50-81.

Bayer, Patrick J., B. Douglas Bernheim, and John Karl Scholz (1996). "The Effects of Financial Education in the Workplace: Evidence from a Survey of Employers." NBER Working Paper No. 5655 (July).

Bernheim, B. Douglas, and Daniel M. Garrett (1996). "The Determinants and Consequences of Financial Education in the Workplace: Evidence from a Survey of Households." NBER Working Paper No. 5667 (July).

Bertaut, Carol (1998). "Stockholding Behavior of U.S. Households: Evidence from the 19831989 Survey of Consumer Finances," Review of Economics and Statistics, Vol. 80, No. 2 (May), pp. 263-275

Blume, Marshall, and Stephen P. Zeldes (1994). "Household Stockownership Patterns and Aggregate Pricing Theories." Mimeo, Wharton School.

Blumenthal, Marsha, and Joel Slemrod (1992). "The Compliance Cost of the U.S. Individual Income Tax System," National Tax Journal, XLV(2), pp. 185-202.

Bodie, Zvi, Robert C. Merton, and William F. Samuelson (1992). "Labor Supply Flexibility and Portfolio Choice in a Lifecycle Model," Journal of Economic Dynamics and Control, Vol. 16, No. 3/4, pp. 427-450.

Calem, Paul and Loretta Mester (1995). "Consumer Behavior and the Stickiness of Credit Card Interest Rates," American Economic Review, Vol. 85, No. 5 (December), pp. $1327-$ 1336.

Chiteji, Ngina S. and Frank P. Stafford (1999). "Portfolio Choices of Parents and their Children as Young Adults: Asset Accumulation by African-American Families," American Economic Review, Papers and Proceedings, Vol. 89, No. 2 (May), pp. 377-380.

Cox, Donald and Tullio Japelli (1993). "The Effect of Borrowing Constraints on Consumer 
Liabilities," Journal of Money, Credit, and Banking, Vol. 25, No. 3, pp. 445-454.

Dicks-Mireaux, Louis-David L. and Mervyn A. King (1983). "Portfolio Composition and Pension Wealth: An Econometric Study." In Zvi Bodie and John Shoven, eds. Financial Aspects of the U.S. Pension System. Chicago: University of Chicago Press for the NBER, pp. 399-435.

Dynan, Karen, Jonathan Skinner, and Stephen P. Zeldes (1999). "Do the Rich Save More?" Mimeo, Columbia University.

Employee Benefit Research Institute (1998). “U.S. Retirement Income System.” EBRI Fact Sheet (December).

Engen, Eric and William G. Gale (1997). "Debt, Taxes, and the Effects of 401(k) Plans on Household Wealth Accumulation." Mimeo, Brookings Institution (May).

Flavin, Marjorie and Takashi Yamashita (1998). "Owner-Occupied Housing and the Composition of the Household Portfolio Over the Life-Cycle." NBER Working Paper No. 6389 (January).

Gollier, Christian (1999). "What Does Classical Portfolio Theory Have to Say about Household Portfolios?" Paper presented at the European Institute's Conference on Household Portfolios, Florence, Italy (December).

Greene, William H. (1990). Econometric Analysis. New York: Macmillan Publishing Company.

Haliassos, Michael and Carol Bertaut (1995). "Why Do So Few Hold Stocks?" Economic Journal, Vol. 105, No. 432, pp. 1110-1129.

Hoynes, Hilary and Daniel McFadden (1997). "The Impact of Demographics on Housing and Non-Housing Wealth in the United States." In Michael D. Hurd and Naohiro Yashiro, eds. The Economic Effects of Aging in the United States and Japan (Chicago: University of Chicago Press for the NBER), pp. 153-194.

Hubbard, R. Glenn, Jonathan Skinner, and Stephen P. Zeldes (1995). "Precautionary Saving and Social Insurance, “ Journal of Political Economy, Vol. 103, No. 2 (April), pp. 360-399.

Hurd, Michael (1999). "The Portfolio Holdings of the Elderly." Paper presented at the European Institute's Conference on Household Portfolios, Florence, Italy (December).

Investment Company Institute (1998). Mutual Fund Fact Book. Washington, D.C.: The Investment Company Institute.

Jappelli, Tullio (1990). "Who is Credit Constrained in the U.S. Economy?" Quarterly Journal 
of Economics, Vol. 105 (February), pp. 219-234.

Jianakoplos, Nancy and Alexandra Bernasek (1998). "Are Women More Risk Averse?” Economic Inquiry, Vol. 36 (October), pp. 620-630.

Kennickell, Arthur B., and Martha Starr-McCluer (1997). "Household Saving and Portfolio Change: Evidence from the 1983-89 SCF Panel" (with Arthur Kennickell), Review of Income and Wealth, Series 43, No. 4 (December), pp. 1-19.

Kennickell, Arthur B., Martha Starr-McCluer, and Brian Surette (2000). "Recent Changes in U.S. Family Finances: Results from the 1998 Survey of Consumer Finances," Federal Reserve Bulletin (January), pp. 1-29.

King, Mervyn, and Jonathan Leape (1998). "Wealth and Portfolio Composition: Theory and Evidence," Journal of Public Economics, Vol. 69, No. 3, pp. 155-193. and Jonathan Leape (1987). "Asset Accumulation, Information, and the Life Cycle." NBER Working Paper No. 2392 (September). , and Louis-David Dicks-Mireaux (1982). "Asset Holdings and the Life Cycle," Economic Journal, Vol. 92 (June), pp. 247-267.

Ladd, H.F. (1998). "Evidence on Discrimination in Mortgage Lending," Journal of Economic Perspectives, Vol. 12, No. 2 (Spring), pp. 41-62.

Loury, Glenn C. (1998). “Why More Blacks Don't Invest,” New York Times, June 6, pp. 70-71.

Maki, Dean M. (1996). "Portfolio Shuffling and Tax Reform," National Tax Journal, Vol. XLIX, No. 3 (September), pp. 317-329.

Mankiw, N. Gregory, and Davil N. Weil (1989). "The Baby Boom, the Baby Bust, and the Housing Market," Regional Science and Urban Economics, Vol. 19, pp. 235-258.

McFadden, Daniel (1994). "Demographics, the Housing Market, and the Welfare of the Elderly." In David Wise, ed., Studies in the Economics of Aging (Chicago: University of Chicago Press for the NBER).

Merton, Robert C. (1969). "Lifetime Portfolio Selection Under Uncertainty: The Continuous Time Case," Review of Economics and Statistics, Vol. 51 (August 1969), pp. 247-257.

Miniaci, Raffaele, Loriana Pelizzon, and Guglielmo Weber (1999). "Econometric Issues in the Estimation of Household Portfolio Models." Paper presented at the European Institute's Conference on Household Portfolios, Florence, Italy (December).

Paxson, Christina (1990). "Borrowing Constraints and Portfolio Choice," Quarterly Journal 
of Economics, Vol. 105 (?): 535-543.

Poterba, James M. (1998). "Population Age Structure and Asset Returns: An Empirical Investigation.” NBER Working Paper No. 6774 (October).

(1999). “Taxation and Portfolio Structure: Issues and Implications." Paper presented at the European Institute's Conference on Household Portfolios, Florence, Italy (December).

Poterba, James M. and Andrew Samwick (1995). "Stock Ownership Patterns, Stock Market Fluctuations, and Consumption," Brookings Papers on Economic Activity, No. 2, pp. 295-372.

NBER Working Paper No. 6185 (September).

Rea, John D. and Brian K. Reid (1998). "Trends in the Ownership Cost of Equity Mutual Funds," Investment Company Institute Perspective, Vol. 4, No. 3 (November).

Samuelson, Paul A. (1969). "Lifetime Portfolio Selection by Dynamic Stochastic Programming," Review of Economics and Statistics, Vol. 51 (August 1969), pp. 239-246.

Shiller, Robert J. (1997). "Human Behavior and the Efficiency of the Financial System." In John B. Taylor and Michael Woodford, Handbook of Macroeconomics. Manuscript, September 1997.

Starr-McCluer, Martha (2000). "Stock Market Wealth and Consumer Spending," mimeo, February (updated version of Federal Reserve Board FEDS Discussion Paper \#98-20, April 1998).

Stewart, Kenneth J. and Stephen B. Reed, "Consumer Price Index Research Series Using Current Methods, 1978-98," Monthly Labor Review, Volume 122, Number 6 (June 1999), pp. $29-38$

Uhler, R.S. and J.G. Cragg (1971). "The Structure of the Asset Portfolios of Households," Review of Economics and Statistics, Vol. 38, pp. 341-357.

Vissing-Jorgensen, Annette (1999). “Towards an Explanation of Household Portfolio Choice Heterogeneity: Nonfinancial Income and Participation Cost Structures." Mimeo, University of Chicago (March).

Weisbenner, Scott (1999). "Do Pension Plans with Participant Investment Choice Teach Households to Hold More Equity?" Federal Reserve Board FEDS Discussion Paper 1999-61(November). 